||||||||||||||||||||||||||||||||||||

\title{
炭素繊維のアルミニウムによる強度劣化，ぬれ性 および接着性に及ぼすアルミナ被覆の効果
}

\author{
北原 晃*. 秋山 茂* .上野 英俊*
}

Effects of alumina coating on degradation, wettability and bonding ability of carbon fiber with aluminum

Akira KITAHARA*, Shigeru AKIYAMA* and Hidetoshi UENO*

\begin{abstract}
Alumina coating on carbon fiber by ion-plating method was investigated in terms of a reaction barrier between PANbased (ungraphitized) carbon fiber and aluminum. The carbon fiber coated directly with aluminum produced carbide $\left(\mathrm{Al}_{4} \mathrm{C}_{3}\right)$ on the fiber-aluminum interface and degraded remarkably in strength at temperatures above $723 \mathrm{~K}$, while the carbon fiber coated first with alumina and then with aluminum produced less carbide and did not degrade in strength at temperatures up to $823 \mathrm{~K}$. These results indicated the availability of alumina coating as a reaction barrier. The alumina coating, however, had no good wettability and bonding ability with aluminum. The alumina coated carbon fiber was additionally coated with aluminum, nickel or titanium to improve these abilities. The aluminum coating improved these abilities without degrading in strength of the fiber after heating, but the nickel and titanium coating caused remarkable degradation in strength of the fibers after heating due to the formation of brittle intermetallic compounds such as $\mathrm{Al}_{3} \mathrm{Ni}$ and $\mathrm{Al}_{3} \mathrm{Ti}$.
\end{abstract}

Keywords: carbon fiber, aluminum, compatibility, alumina coating, ion-plating

(Received September 28, 1989)

\section{1. 緒言}

炭素繊維 (CF) は軽量, 高強度, 高弾性率といら優 れた特性を有することから，繊維強化金属（FRM）の 強化繊維として期待されている。中でも，PAN 系高強 度型 (PAN-II) CF は最も強度が高く，しかも安価で あることから実用性に優れている。しかし，アルミニウ ムに対しては, CF 共通のぬれの悪さに加えて, 高温で の反応による強度劣化が CF の中で最も顕著であり ${ }^{1)}$, PAN-II CF は非常に適合性が悪い。

$\mathrm{CF}$ のアルミニウムに対する適合性を改善する方法と して，CFの表面を化学的に安定なセラミックスで被覆 する方法が種々検討されている(1) 9)。Amateau ${ }^{1)}$ が報告 している CVD 法による Ti-B 被覆は, ぬれ性改善には 有効であるが，PAN-II GF のアルミニウムとの反応に
よる強度劣化は抑制できない。小原ら ${ }^{4), 5)}$ は，GVD法 による $\mathrm{SiC}$ や $\mathrm{TiC}$ 被覆により $\mathrm{CF}$ の反応による強度劣 化を抑制できると報告している。Shindo ら ${ }^{9}$ はこれらの 方法を組合わせて，炭素-SiCの 2 層被覆の上にさらに Ti-B を被覆する方法により $\mathrm{PAN}-$ II GF のアルミニウ ムに対する反応性抑制と好性改善を両立させることに 成功している。しかし，これらの方法で用いる GVD 法 は, 有毒で腐食性が強い塩化物系のガスを用いるため危 険性が高いことや, 装置や工程が複雑なため経済性にも 問題がある。

浅沼ら ${ }^{10)}$ は, FRMをプラズマスプレイ・ロール圧延 法で製造する際に界面に形成される $\gamma-\mathrm{Al}_{2} \mathrm{O}_{3}$ が $\mathrm{PAN}-\mathrm{II}$ $\mathrm{CF}$ とアルミニウムとの反応を抑制し，反応による FRM の強度劣化を防止すると報告している。しかし， $\mathrm{CF}$ の被覆に酸化アルミニウム $\left(\mathrm{Al}_{2} \mathrm{O}_{3}\right)$ を用いた研究

*九州工業技術試験所（鳥栖市）。Government Industrial Research Institute, Kyushu (Tosu-shi, Saga). 


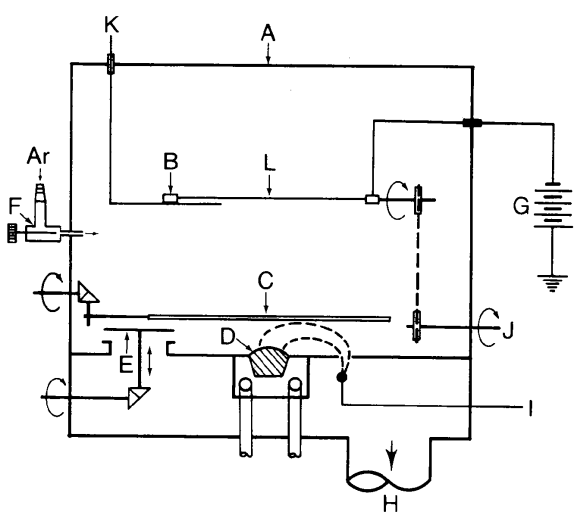

Fig. 1 Apparatus for ion-plating. A: Vacuum chamber. B: Sample holder. C: Shutter. D: E.B. evaporator. E: Variable valve. F: Gas leak valve. G: Bias voltage. H: Evacuator. I: E.B. power supply. J: Rotating device. K: Thermo-couple. L: Carbon fiber.

例はない。一方，イオンプレーティング法 ${ }^{11}$ は, 被膜の つきまわり性や付着性が良く，乙かも安全であることか ら，CFの表面被覆法として期待されている。

そこで本研究では, PAN-II CFのアルミニウムに対 する適合性を改善する安全で経済的な方法として，イ才 ンプレーティングによる $\mathrm{Al}_{2} \mathrm{O}_{3}$ 被覆法の有効性を, $\mathrm{CF}$ のアルミニウムとの反応による強度劣化の防止およびぬ れや接着性の改善の観点から検討した。

\section{2. 実験方法}

\subsection{CF の被覆方法}

用いた PAN-II CF の特性は繊維径 $7 \mu \mathrm{m}$, 引張強さ $3.11 \mathrm{GPa}$, 引張弾性率 $236 \mathrm{GPa}$ ，伸び $1.46 \%$ である。

Fig. 1 にCF の寸べての被覆に用いたイオンプレーテ ヘング装置を示す。 $25 \mathrm{~mm}$ 幅に拡げた 12000 本の CF の トウを， $5 \mathrm{~mm}$ 間隔， 4 列に並べて $200 \times 200 \mathrm{~mm}$ 角の試 料枠に張る。この試料枠を蒸発源 Dより $150 \mathrm{~mm}$ の距離 にある回転基板ホルダー $\mathrm{B}$ に水平に設置する。真空層 $\mathrm{A}$ 内を $2.7 \mathrm{mPa}$ 以下に排気した後, ガス導入バルブ $\mathrm{F} よ$ り $\mathrm{Ar}$ ガスを導入して槽内のガス圧を5.3 Pa に保つ。基 板にー0.5 kV のバイアス電圧 Gを印加して発生させた グロー放電により, $\mathrm{CF}$ 表面を $600 \mathrm{~s}$ 間スパッタクリーニ ングする。次いで, 基板印加電圧を $-1 \mathrm{kV}$, 槽内の $\mathrm{Ar}$ ガス圧を $0.33 \mathrm{~Pa}$ に変え, 電子ビーム蒸発源より被覆材 を加熱蒸発させて, 約 $5 \mathrm{~nm} / \mathrm{s}$ の速度で $\mathrm{GF}$ 表面に所定 膜厚の被膜を形成させる。この際, 被覆を片面からだけ 行うと蒸発源前面と背面での膜厚比が約 $10: 1$ と不均一 となるが，基板枠を半回転させて両面から被覆すること により膜厚はほぼ均一となった。
まず，CF表面にアルミニウムとの反応障壁として， 酸化アルミニウム $\left(99.5 \% \mathrm{Al}_{2} \mathrm{O}_{3}\right)$ を所定厚さ（0.025～ $1.0 \mu \mathrm{m})$ 被覆する*。次に, この $\mathrm{Al}_{2} \mathrm{O}_{3}$ 被膜の上に直接, あるいはアルミニウムとのぬれと接着性を改善するため にニッケル $(99.99 \% \mathrm{Ni})$ またはチタン $(99.99 \% \mathrm{Ti})$ を $0.1 \mu \mathrm{m}$ 被覆した上に，アルミニウム $(99.99 \% \mathrm{Al})$ を 1 $\mu \mathrm{m}$ 被覆して CF とアルミニウムとの単繊維状 FRMを 作成した*。

\section{2 適合性の評価法}

$\mathrm{CF}$ のアルミニウムとの反応に及ぼす $\mathrm{Al}_{2} \mathrm{O}_{3}$ の反応障 壁効果を調べるため, 単繊維状 FRM を Ar ガス雾囲気 中で所定温度 $T$ にて $18 \mathrm{ks}$ 間熱処理した。

$\mathrm{GF}$ の反応による強度劣化は, 熱処理した単繊維状 FRM の引張強さ $\sigma$ の熱処理前の引張強さ $\sigma_{0}$ に対する 相対強度 $\sigma / \sigma_{0}$ により評価した。FRMの引張試験は, ゲージ長 $25 \mathrm{~mm}$, 引張速度 $8.3 \mu \mathrm{m} / \mathrm{s}$, 測定本数 50 本で行 った。なお，CFに較べ被膜の強度が非常に小さいと考 えられたので, 引張強さは被膜による繊維径の増分を無 視して算出した。また, 引張強さの $95 \%$ 信頼度区間が平 均約 $7 \%$ であったので，相対強度が0.93を下まわったと き強度劣化したと判断した。

FRM の反応形態は X 線回折および走査電顕観察によ り調べた。X 線回折には, 回転対陰極 $(\mathrm{Cu})$ 型 X 線源 とディフラクトメーター式回折装置を用いた。単繊維状 FRM は，12000本のトウを幅10 mm に拡げ，発散およ び受光スリットと䋐維軸が直角になるようにガラス製の 試料ホルダーに張り付けた。一方, 走査電顕では, 最初 にFRMの被膜の表面形態を観察した。その後, $303 \mathrm{~K}$ の $10 \% \mathrm{NaOH}$ 水溶液に $300 \mathrm{~s}$ 間浸漬し, アルミニウム拉 よび $\mathrm{Al}_{2} \mathrm{O}_{3}$ 被膜を除去した $\mathrm{CF}$ の表面形態を観察した。

$\mathrm{CF}$ とアルミニウムのぬれと接着性を直接定量的に評 価するのは困難なので，黒鉛基板（Gr）を用いたシミ ニレーション実験を行った。固定炭素 $99.85 \%$ ， みかけ 比重1.76, 引張強さ18.3 MPa の高純度黒鉛質れんがか ら，20×20×3 mm のぬれ試験片と $\phi 11 \times 20 \mathrm{~mm}$ の接着 性試験片を切出した。これらの $\mathrm{Gr}$ の試験面を $0.3 \mu \mathrm{m} の$ アルミナ研磨材で鏡面にバフ仕上げした後, GF と同じ 条件で表面被覆を行った。

ぬれ性は, 静滴法（Sessile drop 法）で測定した純ア ルミニウム $(99.99 \% \mathrm{Al})$ 液滴 $(0.15 \mathrm{~g})$ の $\mathrm{Gr}$ 基板に対 する接触角 $\theta$ により評価した。測定は真空中（<0.67 $\mathrm{mPa})$, 測定温度範囲 $973 \sim 1273 \mathrm{~K}$, 昇温速度約 $0.055 \mathrm{~K} /$ $\mathrm{s}$ の条件で行った。

一方，接着性は，アルミニウムで融接した $\mathrm{Gr}$ 基板の

* 膜厚 $1.0 \mu \mathrm{m}$ のアルミニウム以外の被膜には膜厚を $\mu \mathrm{m}$ 単位で付して, $\mathrm{CF} / 0.25 \mathrm{Al}_{2} \mathrm{O}_{3} / 0.1 \mathrm{Ni} / \mathrm{Al}$ のよう に表記する。 

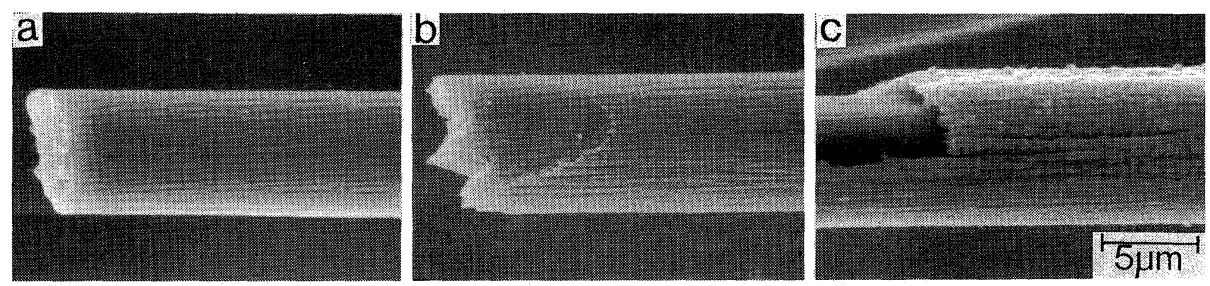

Fig. 2 SEM micrographs of PAN-II type carbon fiber and coated carbon fibers by ion-plating. (a) GF, (b) GF/ $0.25 \mathrm{Al}_{2} \mathrm{O}_{3}$, (c) $\mathrm{CF} / 0.25 \mathrm{Al}_{2} \mathrm{O}_{3} / \mathrm{Al}$.

接着強度（引張強さ）Bにより評価した。円柱状 $\mathrm{Gr}$ の 間に厚さ $0.5 \mathrm{~mm}$ のアルミニウム $(99.5 \%)$ 䇴を挟み, 黒鉛製の鞘に入れ, 荷重 $(100 \mathrm{~g})$ をかけながら, 真空 中（<67 mPa） で973 K に1.8 ks 間加熱保持して融接を 行った。この接合試験片の側面を $\phi 9 \mathrm{~mm}$ に旋削加工し て,引張試験片とした。

\section{3. 実験結果および考案}

\section{1 被膜の形態}

$\mathrm{CF}$ および各種の被覆をした CF の走査電顕写真を

Fig. 2 に, X 線回折パターンをFig. 3 に示す。

$\mathrm{Al}_{2} \mathrm{O}_{3}$ 被膜（Fig. 2(b)）は, PAN 系 $\mathrm{CF}$ の特徵であ る繊維軸方向の筋状溝（Fig. 2(a)）が強調されて深く なっているのを除けば非常に平滑で，しかもX線回折 (Fig. 3(c)) で $\mathrm{Al}_{2} \mathrm{O}_{3}$ のピークが検出されないことから， 非晶質化していると考学られる。一方，アルミニウム被 膜（Fig. 2(c)）は，表面にかなり粗い凹凸があり，X 線回折 (Fig. 3(a), (e)) で $\mathrm{Al}$ のピークが検出され, 結 晶質である。

\section{2 被覆 $\mathrm{GF}$ の強度}

$\mathrm{CF}$ および各種の被覆をした CF の引張強さ $\sigma_{0}$ とその ワイブル形状係数 $m^{* *}$ Table 1 に示す。

$\mathrm{CF} / \mathrm{Al}$ の $\sigma_{0}$ と $m$ はともに非被覆の $\mathrm{CF}$ とほととど変 わらない。しかし， $\mathrm{CF} / \mathrm{Al}_{2} \mathrm{O}_{3}$ の $\sigma_{0}$ と $m$ はともに大き く低下する。 $\sigma_{0}$ が低下するのは, $\mathrm{Al}_{2} \mathrm{O}_{3}$ 被膜が脆弱で $\mathrm{CF}$ の破壊応力に達する以前のひずみで破壊し，その破 壊がCFにも伝搬するためで，一方， $m$ が低下するの は，応力集中を生じ，破壊の起点となる欠陥が，CFよ り $\mathrm{Al}_{2} \mathrm{O}_{3}$ 被膜においてより不均質なためだと考えられ る。 $\mathrm{CF} / \mathrm{Al}_{2} \mathrm{O}_{3} / \mathrm{Al}$ では， $\sigma_{0}$ と $m$ はともにかなり回復す る。これは $\mathrm{Al}_{2} \mathrm{O}_{3}$ 被膜の表面欠陥が延性なアルミニウム で埋められたためと考えられる。

\section{$3.3 \mathrm{CF} / \mathrm{Al}$ 熱処理材の強度劣化}

$\mathrm{CF} / \mathrm{Al}$ 熱処理材の相対強度 $\sigma / \sigma_{0}(\bullet)$ の熱処理温度

** 小原 ${ }^{4), 5)}$ の報告同様, $\mathrm{CF}$ 抢よび被覆状態の CF とも 2 パラメータワイブル分布に従ら。

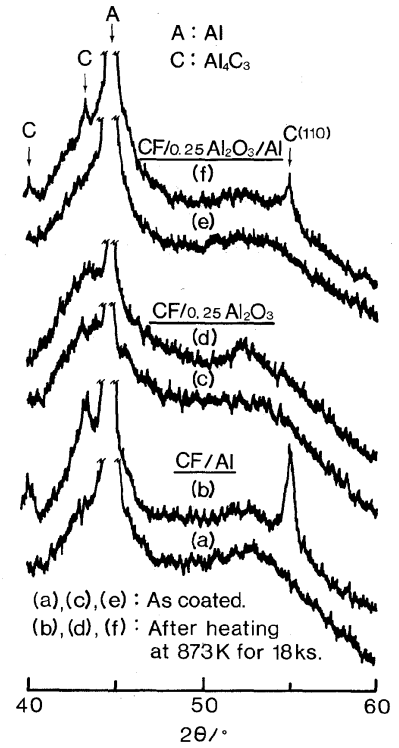

Fig. 3 X-ray $\left(\mathrm{Cu}-\mathrm{K}_{\alpha}\right)$ diffraction patterns of coated carbon fibers.

Tに対するプロットをFig. 4 に示す。また，これらの 引張強さのワイブル分布プロットを Fig. 5 に示す。

$T$ が723 K になると $\mathrm{GF} / \mathrm{Al}$ は $\sigma / \sigma_{0}$ が低下し, 強度劣 化が始まる。Tの上昇に伴い強度劣化は進行して, 873 $\mathrm{K}$ では $\boldsymbol{\sigma} / \sigma_{0}$ が0.5 以下にまで低下する（Fig. 4)。この 強度劣化した $\mathrm{CF} / \mathrm{Al}$ では， $\sigma$ の分布が低強度側に移動 するだけでなく，分布の形態が変わる（Fig. 5)。すな わち, 高強度側では被覆状態とほぼ等しい勾配（ワイブ ル形状係数 $m$ が約4.7）の直線に一致し，低強度側では 低勾配の直線に一致する，いわゆる混合型のワイブル分 布13)をとる。

低強度側の破断（初期破断）の要因は, 当然のことな がら熱処理により新たに生じたものである。ここで, 強 度劣化した $\mathrm{CF} / \mathrm{Al}$ では, $\mathrm{Al}_{4} \mathrm{C}_{3}$ の生成が $\mathrm{X}$ 線回折 (Fig. 3(b)，Table 1) 执よび走査電顕観察（Fig. 6(a)， (b)）により確認された。さらに，Tが723，773，823， $873 \mathrm{~K}$ と上昇し反応が進行して $\mathrm{Al}_{4} \mathrm{C}_{3}$ の生成量が増加す 
Table 1 Tensile strength $\left(\sigma_{0}\right)$ and its weibull coefficient $(m)$ for carbon fiber and coated carbon fibers by ion-plating, and intensity $(I)$ of $\mathrm{Al}_{4} \mathrm{C}_{3}(110)$ peak obtained from X-ray $\left(\mathrm{Cu}-\mathrm{K}_{\alpha}\right)$ diffraction pattern for aluminum coated carbon fibers heated for $18 \mathrm{ks}$ at temperature $(T)$ range from 673 to $873 \mathrm{~K}$. The thickness of coatings are noted in $\mu \mathrm{m}$. Aluminum coating thickness is $1 \mu \mathrm{m}$

\begin{tabular}{|c|c|c|c|c|c|c|c|}
\hline \multirow{3}{*}{ Coating } & \multirow{3}{*}{$\sigma_{0} / \mathrm{GPa}$} & \multirow{3}{*}{$m$} & \multicolumn{5}{|c|}{$T / \mathrm{K}$} \\
\hline & & & 673 & 723 & 773 & $\cdot 823$ & 873 \\
\hline & & & \multicolumn{5}{|c|}{$I /$ count } \\
\hline Non & $3.10 \pm 0.20$ & 4.96 & - & - & - & - & - \\
\hline $\mathrm{Al}$ & $3.05 \pm 0.15$ & 4.81 & $*$ & 1720 & 5390 & 7800 & 11580 \\
\hline $0.25 \mathrm{Al}_{2} \mathrm{O}_{3}$ & $2.67 \pm 0.18$ & 2.74 & - & - & - & - & - \\
\hline $1.0 \mathrm{Al}_{2} \mathrm{O}_{3} / \mathrm{Al}$ & $2.76 \pm 0.21$ & 3.78 & $*$ & $*$ & $*$ & $*$ & 1330 \\
\hline $0.5 \mathrm{Al}_{2} \mathrm{O}_{3} / \mathrm{Al}$ & $2.74 \pm 0.20$ & 3.71 & $*$ & * & $*$ & * & 2820 \\
\hline $0.25 \mathrm{Al}_{2} \mathrm{O}_{3} / \mathrm{Al}$ & $2.75 \pm 0.22$ & 3.23 & $*$ & $*$ & $*$ & $*$ & 3760 \\
\hline $0.125 \mathrm{Al}_{2} \mathrm{O}_{3} / \mathrm{Al}$ & $2.82 \pm 0.23$ & 3.66 & * & $*$ & * & 1530 & 4910 \\
\hline $0.05 \mathrm{Al}_{2} \mathrm{O}_{3} / \mathrm{Al}$ & $2.89 \pm 0.22$ & 3.69 & $*$ & $*$ & $*$ & 3470 & 7490 \\
\hline $0.025 \mathrm{Al}_{2} \mathrm{O}_{3} / \mathrm{Al}$ & $2.76 \pm 0.19$ & 3.75 & $*$ & $*$ & 770 & 5830 & 9240 \\
\hline $0.25 \mathrm{Al}_{2} \mathrm{O}_{3} / 0.1 \mathrm{Ni} / \mathrm{Al}$ & $2.59 \pm 0.20$ & 3.75 & * & $*$ & $*$ & $*$ & 1556 \\
\hline $0.25 \mathrm{Al}_{2} \mathrm{O}_{3} / 0.1 \mathrm{Ti} / \mathrm{Al}$ & $2.61 \pm 0.17$ & 3.57 & $*$ & $*$ & * & * & 2083 \\
\hline
\end{tabular}

*: undetected

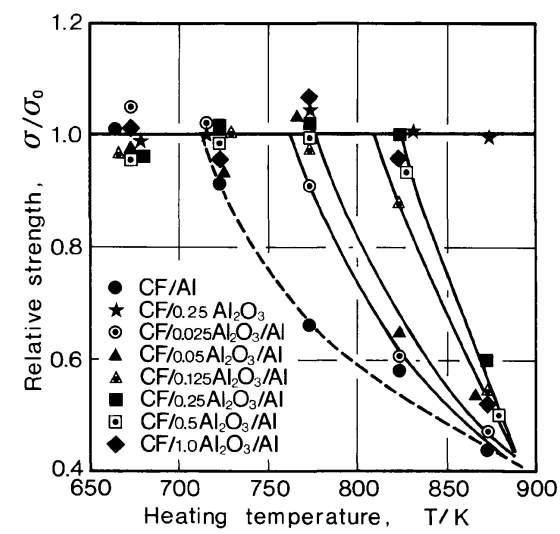

Fig. 4 Relative strength vs heating temperature curves for coated carbon fibers after heating for 18 ks.

る（Table 1）に従って，初期破断する試料の累積頻度 の推定值 $P$ はそれぞれ $42,65,77,90 \%$ と上昇する。しか し，このPの值をもとに $\sigma$ を再プロットして求めた $m$ はそれぞれ2.29, $1.98,1.89,1.90$ と, プロット数が少な い723 K を除けばほぼ等しい值をとり, 強度劣化は同じ 要因で生じているといえる。これらの結果は, 低強度側 の破断の要因が $\mathrm{CF} / \mathrm{Al}$ の反応による強度劣化の原因と されている(14) $\mathrm{Al}_{4} \mathrm{C}_{3}$ の生成であるといらことを示唆して いる。

この $\mathrm{Al}_{4} \mathrm{C}_{3}$ の生成に起因する繊維の破断強度は $m$ が 約 2 と小さく, 被覆状態のものに比べても非常にばらつ

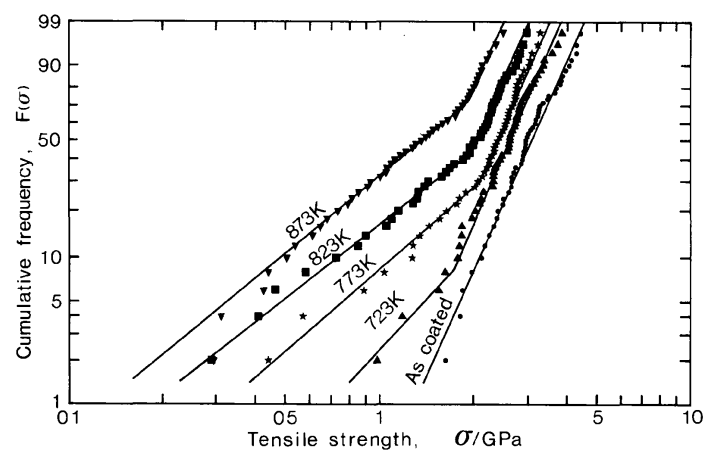

Fig. 5 Weibull plots of the tensile strength of aluminum coated carbon fibers after heating for 18 ks at temperature range from 723 to $873 \mathrm{~K}$.

きが大きい。Kohara ら ${ }^{12)}$ は, $\mathrm{GF} / \mathrm{Al}$ の反応による強度 劣化の直接の要因はFig. 6(b)にみられるような $\mathrm{Al}_{4} \mathrm{C}_{3}$ の六角形結晶が CF の内部に成長した部分（根）の切欠 効果であると推定している。このような不均一反応に依 存して, しかも切欠効果による破断強度は, 本実験のよ らに $m$ の值が小さく, ばらつきが大きくなるのも当然 であろら。

\section{$3.4 \mathrm{CF} / \mathrm{Al}_{2} \mathrm{O}_{3} / \mathrm{Al}$ 熱処理材の強度劣化}

$\mathrm{GF} / \mathrm{Al}_{2} \mathrm{O}_{3}$ 打よび $\mathrm{CF} / \mathrm{Al}_{2} \mathrm{O}_{3} / \mathrm{Al}$ 熱処理材の相対強度 $\sigma / \sigma_{0}$ を, $\mathrm{CF} / \mathrm{Al}$ と同じ Fig. 4 で熱処理温度 $T$ に対して

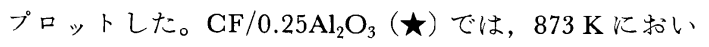
ても強度が劣化しない。また，X線回折パターン (Fig. 3(c), (d)) にも変化がみられない。さらに, $\mathrm{Al}_{2}$ 

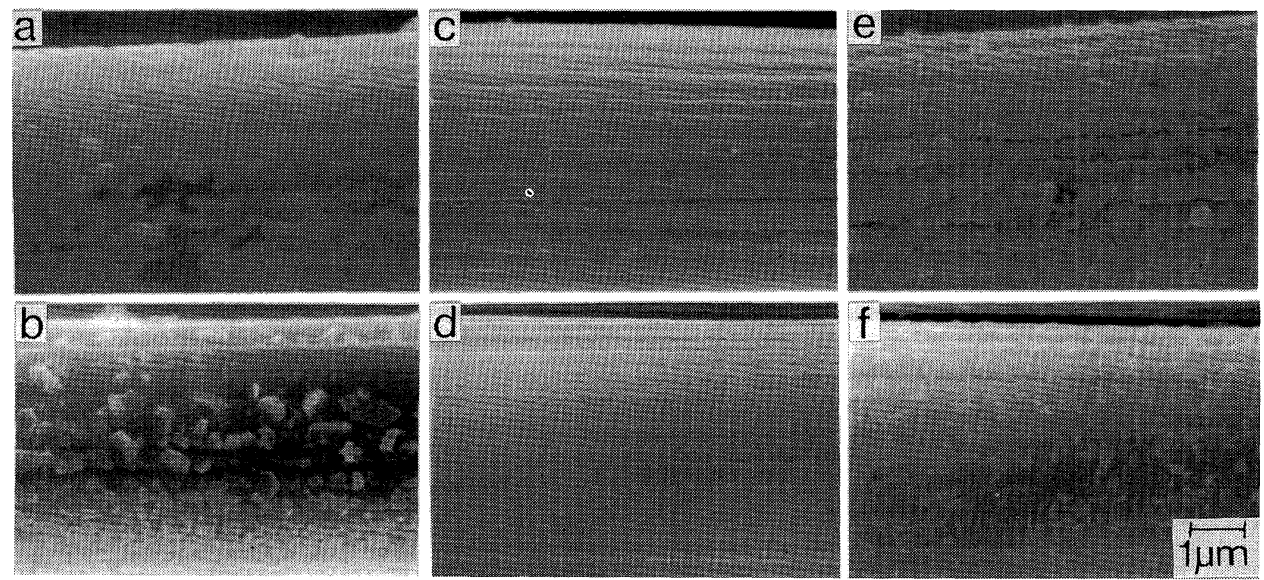

Fig. 6 SEM micrographs for coated carbon fibers after heating at $873 \mathrm{~K}$ for $18 \mathrm{ks}$ and leaching with $10 \% \mathrm{NaOH}$ solution at $303 \mathrm{~K}$ for $300 \mathrm{~s}$. (a, b) $\mathrm{CF}$, (c, d) $\mathrm{CF} / 0.25 \mathrm{Al}_{2} \mathrm{O}_{3}$, (e, f) $\mathrm{CF} / 0.25 \mathrm{Al}_{2} \mathrm{O}_{3} / \mathrm{Al}$, and (a, c, e) after heating, (b, d, f) after leaching.

$\mathrm{O}_{3}$ 被膜およびこの被膜を除去した $\mathrm{CF}$ の表面の走查電 顕観察（Fig. 6(c)，(d)) でも反応の跡はみられない。 これらのことは, $873 \mathrm{~K}$ に扔いても $\mathrm{CF}$ と $\mathrm{Al}_{2} \mathrm{O}_{3}$ の間で は GF の強度劣化をもたらすような反応が生じていない ことを示している。

一方, $\mathrm{CF} / \mathrm{Al}_{2} \mathrm{O}_{3} / \mathrm{Al}$ は熱処理により強度劣化するが, その強度劣化開始温度か $\mathrm{Al}_{2} \mathrm{O}_{3}$ 膜厚の増加と共に上昇 し， $0.25 \mu \mathrm{m} （$ - $)$ では $\mathrm{CF} / \mathrm{Al}$ より $100 \mathrm{~K}$ 以上高い 823 $\mathrm{K}$ にまで上昇する。これに対応して, 強度劣化が抑制 されたものでは X 線回折の $\mathrm{Al}_{4} \mathrm{C}_{3}$ のピークが検出され ない。また強度劣化したものでも $\mathrm{Al}_{2} \mathrm{O}_{3}$ 膜厚の増加に伴 って $\mathrm{Al}_{4} \mathrm{C}_{3}$ のピーク強度 $I$ が減少し (Table 1), 走査電 顕では, アルミニウム被膜の反応の形跡 (Fig. 6(e)) や $\mathrm{CF}$ 表面の $\mathrm{Al}_{4} \mathrm{C}_{3}$ の生成量（Fig. 6(f)）が著しく減少す ることが観察された。これらのことから， CF とアルミ ニウムとの反応障壁として $\mathrm{Al}_{2} \mathrm{O}_{3}$ 被膜が有効なことがわ かった。

浅沼ら ${ }^{10)}$ 恃, $\gamma-\mathrm{Al}_{2} \mathrm{O}_{3}$ 被膜により, アルミニウムとの 反応による $\mathrm{CF}$ の強度劣化が $873 \mathrm{~K}$ において子防止され ると報告している。しかし本実験の $\mathrm{Al}_{2} \mathrm{O}_{3}$ 被膜では, 膜 厚を $1 \mu \mathrm{m}$ まで厚くしても, $873 \mathrm{~K} て ゙ は \mathrm{CF}$ とアルミ ウムとの反応が抑制されず $\mathrm{Al}_{4} \mathrm{C}_{3}$ が生成し（Table 1),

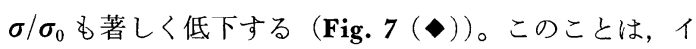
オンプレーティングによる $\mathrm{Al}_{2} \mathrm{O}_{3}$ 被膜が非晶質であるた め, 結晶質の $\gamma-\mathrm{Al}_{2} \mathrm{O}_{3}{ }^{10)}$ 亿較べて反応イオンの拡散が容 易で, 反応障壁効果が劣ることを示唆している。

Fig. 7 に $\mathrm{CF} / \mathrm{Al}$ と $\mathrm{CF} / \mathrm{Al}_{2} \mathrm{O}_{3} / \mathrm{Al}$ 熱処理材の $\sigma / \sigma_{0}$ を $I$ に対してプロットした。 $\mathrm{GF} / \mathrm{Al}$ 熱処理材ではOkura ら ${ }^{15)}$ の結果と同様に, 引張強さが $I$ の増加に伴い, 低下し

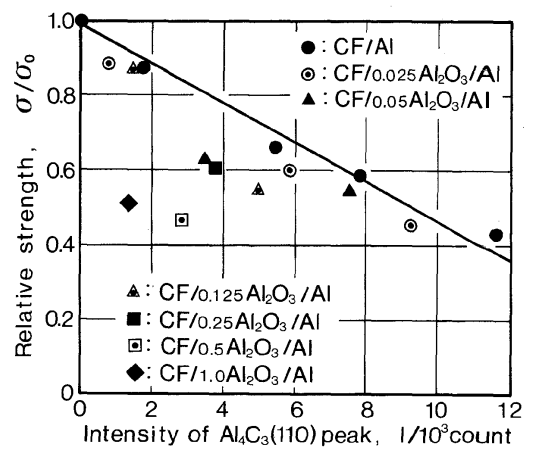

Fig. 7 Relation between relative strength of coated carbon fibers heated at $873 \mathrm{~K}$ for $18 \mathrm{ks}$ and intensity of $\mathrm{Al}_{4} \mathrm{C}_{3}(110)$ peak in $\mathrm{X}$-ray $\left(\mathrm{Cu}-\mathrm{K}_{\alpha}\right)$ diffraction pattern.

ている。 $\mathrm{CF} / \mathrm{Al}_{2} \mathrm{O}_{3} / \mathrm{Al}$ では $\mathrm{Al}_{2} \mathrm{O}_{3}$ の膜厚が増すに従っ て同じ $\mathrm{Al}_{4} \mathrm{C}_{3}$ 生成量に対する強度低下の度合が大きくな り, 反応以上る強度劣化感受性が高くなる傾向が認めら れる。この観点から, 被膜はなるべく薄い方がよく, $\mathrm{CF}$ とアルミニウムとの反応障壁としての $\mathrm{Al}_{2} \mathrm{O}_{3}$ の膜厚 は強度劣化の開始温度が飽和する膜厚 $0.25 \mu \mathrm{m}$ が適切な 厚さといえる。

\section{$3.5 \mathrm{Gr} / \mathrm{Al}_{2} \mathrm{O}_{3}$ 被膜のアルミニウムとのぬれと接着性}

Fig. 8 は, $\mathrm{Gr}(\bullet)$ と $\mathrm{Gr} / 0.25 \mathrm{Al}_{2} \mathrm{O}_{3}(\star)$ に対するア ルミニウム液滴の接触角 $\theta$ を測定温度 $T$ に対してプロ ットしたものである。

Gr では973 K で $\theta$ が約 $150^{\circ}$ 之非常に好机が悪いが，

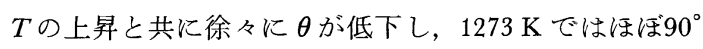
まで低下してぬれのよい状態となる。 $\mathrm{Gr} / 0.25 \mathrm{Al}_{2} \mathrm{O}_{3}$ で 


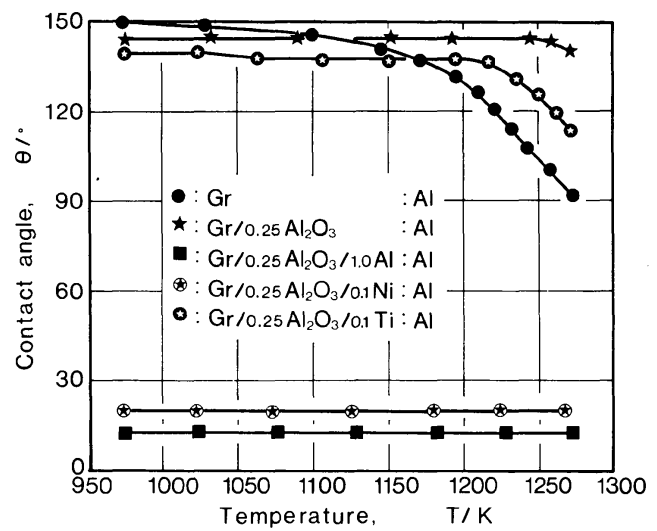

Fig. 8 Contact angle between coated graphite and liquid aluminum as a function of temperature.

Table 2 Bonding strength $(B)$ between coated graphites and aluminum. The thickness of coatings are noted in $\mu \mathrm{m}$

\begin{tabular}{l|r}
\hline \multicolumn{1}{c|}{ Coating } & $B / \mathrm{MPa}$ \\
\hline $\mathrm{Non}$ & 3.16 \\
$1.0 \mathrm{Al}$ & 8.53 \\
$0.25 \mathrm{Al}_{2} \mathrm{O}_{3}$ & 7.16 \\
$0.25 \mathrm{Al}_{2} \mathrm{O}_{3} / 1.0 \mathrm{Al}$ & 14.2 \\
$0.25 \mathrm{Al}_{2} \mathrm{O}_{3} / 0.1 \mathrm{Ni}$ & $>18.3$ \\
$0.25 \mathrm{Al}_{2} \mathrm{O}_{3} / 0.1 \mathrm{Ti}$ & $>18.3$ \\
\hline
\end{tabular}

は $\theta$ は973 Kから $1250 \mathrm{~K}$ までは $145^{\circ}$ とほぼ一定で， $1250 \mathrm{~K}$ を超えるとわずかに低下の傾向がみられる。す なわち, $\mathrm{Gr}$ とアルミニウムのぬれの悪さは $\mathrm{Al}_{2} \mathrm{O}_{3}$ の被 覆によっては改善されず, $1100 \mathrm{~K}$ 以上の高温では $\mathrm{Gr}$ よ りもかえってぬれが悪くなる。

そこで, $\mathrm{Al}_{2} \mathrm{O}_{3}$ 被膜のアルミニウムに対するぬれの悪 さを改善する目的で, $\mathrm{Al}_{2} \mathrm{O}_{3}$ 被膜の上に $1 \mu \mathrm{mAl}$ (匹), $0.1 \mu \mathrm{m} \mathrm{Ni}$ ま または $0.1 \mu \mathrm{m} \mathrm{Ti}(\circlearrowleft)$ を被覆し，その 結果をFig. 8 に示す。 $\mathrm{Gr}$ の場合 ${ }^{16), 17)}$ と同様に, $1 \mu \mathrm{m}$ $\mathrm{Al}$ および $0.1 \mu \mathrm{m} \mathrm{Ni}$ 被覆により, $\theta$ が測定開始の $873 \mathrm{~K}$ においてすでに $15^{\circ}$ および $20^{\circ}$ 以下にまで低下し，ぬれ性 が著しく改善される。しかしながら，0.1 $\mu \mathrm{m}$ Ti 被覆は ほとんど効果がない。

Table 2 にG および各種の被覆をした Grのアル ニウムとの接着力 $B$ を示す。 $\mathrm{Gr}$ と $\mathrm{Gr} / 0.25 \mathrm{Al}_{2} \mathrm{O}_{3}$ では 接着力が弱く, 接着界面ではく離が生じる。 $\mathrm{Gr} / 0.25 \mathrm{Al}_{2}$ $\mathrm{O}_{3} / 1.0 \mathrm{Al}$ では接着力がかなり向上し, 界面はく離が全 面には及ばず，Gr内での破断がみられるよらになる。 $\mathrm{Gr} / 0.25 \mathrm{Al}_{2} \mathrm{O}_{3} / 0.1 \mathrm{Ni}$ と $\mathrm{Gr} / 0.25 \mathrm{Al}_{2} \mathrm{O}_{3} / 0.1 \mathrm{Ti}$ では接着力

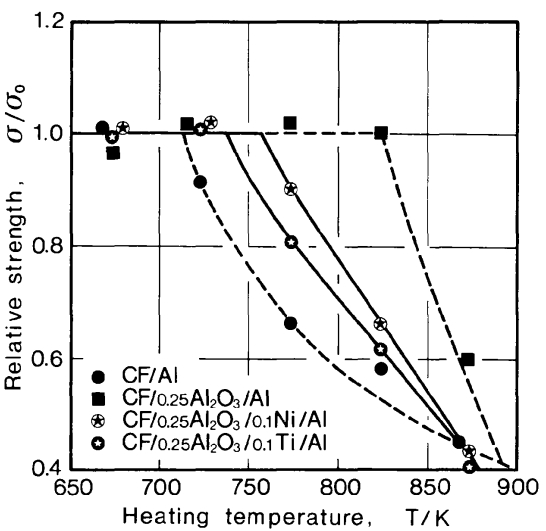

Fig. 9 Relative strength vs heating temperature curves for coated carbon fibers after heating for 18 ks.

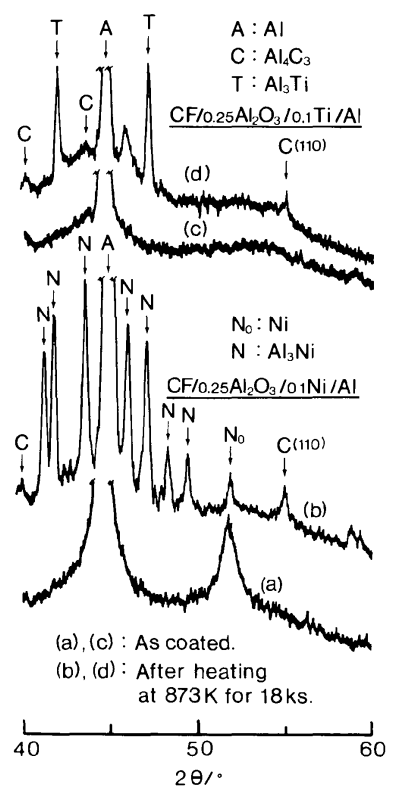

Fig. $10 \mathrm{X}$-ray $\left(\mathrm{Cu}-\mathrm{K}_{\alpha}\right)$ diffraction patterns of coated carbon fibers.

がさらに向上して，接着界面ではく離せず $\mathrm{Gr}$ 部におい て破断するようになる。すなわち, 接着力は Grの引張 強さ18.3 $\mathrm{MPa}$ 以上と強くなっている。

\section{3. $6 \mathrm{CF} / 0.25 \mathrm{Al}_{2} \mathrm{O}_{3} / 0.1 \mathrm{Ni} / \mathrm{Al}$ ¿ $\mathrm{GF} / 0.25 \mathrm{Al}_{2} \mathrm{O}_{3} / 0.1$} $\mathrm{Ti} / \mathrm{Al}$ 熱処理材の強度劣化

Fig. 9 は，反応障壁としての $\mathrm{Al}_{2} \mathrm{O}_{3}$ 被膜の上に $\mathrm{Al}$ と のぬれ性あるいは接着性を改善するために Ni および $\mathrm{Ti}$ を被覆して作った単繊維状 FRM 熱処理材の相対強 度 $\sigma / \sigma_{0}$ を熱処理温度 $T$ に対してプロットしたものであ る。 


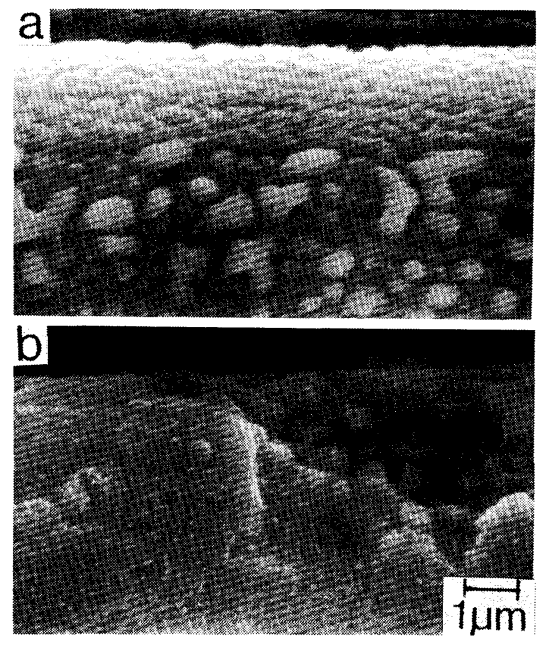

Fig. 11 SEM micrographs of coated carbon fibers after heating at $873 \mathrm{~K}$ for $18 \mathrm{ks}$. (a) $\mathrm{CF} / 0.25 \mathrm{Al}_{2} \mathrm{O}_{3} /$ $0.1 \mathrm{Ni} / \mathrm{Al}$, (b) $\mathrm{CF} / 0.25 \mathrm{Al}_{2} \mathrm{O}_{3} / 0.1 \mathrm{Ti} / \mathrm{Al}$.

データは示していないが, $\mathrm{CF} / 0.25 \mathrm{Al}_{2} \mathrm{O}_{3} / 0.1 \mathrm{Ni}$ お び $\mathrm{CF} / 0.25 \mathrm{Al}_{2} \mathrm{O}_{3} / 0.1 \mathrm{Ti}$ は873 K においても強度劣化せ ず，X 線回折や走査電顕観察にも変化が認められない。 すなわち， $\mathrm{Al}_{2} \mathrm{O}_{3}$ と $\mathrm{Ni}$ および $\mathrm{Ti}$ との間では強度劣化を もたらすような反応は生じていない。

一方, $\mathrm{CF} / 0.25 \mathrm{Al}_{2} \mathrm{O}_{3} / 0.1 \mathrm{Ni} / \mathrm{Al}\left(\mathrm{CF} / 0.25 \mathrm{Al}_{2} \mathrm{O}_{3}\right.$

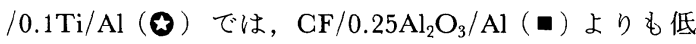
温の773 Kから強度劣化が開始する（Fig. 9）。しかし， $873 \mathrm{~K}$ の熱処理材では $\mathrm{Al}_{4} \mathrm{C}_{3}$ が検出されるが, 強度劣化 が起こっているにもかかわらず773〜 $823 \mathrm{~K}$ の熱処理材 では検出されない（Table 1)。その代わりに，第 2 層の $\mathrm{Ni}$ あるいは $\mathrm{Ti}$ とアルミニウムとの反応による金属間化 合物 $\mathrm{Al}_{3} \mathrm{Ni}$ あるいは $\mathrm{Al}_{3} \mathrm{Ti}$ (Fig. 10(b)，(d)) が検出さ れる。またこれらの熱処理材の走査電顕観察では, 被覆 層内で顕著な反応が生じていることが認められる (Fig. 11(a), (b))。これらのことから, $\mathrm{CF} / 0.25 \mathrm{Al}_{2} \mathrm{O}_{3} /$ $0.1 \mathrm{Ni} / \mathrm{Al}$ と $\mathrm{CF} / 0.25 \mathrm{Al}_{2} \mathrm{O}_{3} / 0.1 \mathrm{Ti} / \mathrm{Al}$ の強度劣化は主と して脆弱な金属間化合物の生成によることが明らかで, $\mathrm{Ni}$ や $\mathrm{Ti}$ 被覆はぬれや接着性の改善には有効でも, 反応 による強度劣化の面からは好ましくないことがわかる。

\section{4. 結言}

PAN 系高強度型炭素繊維 $(\mathrm{CF})$ のアルミニウムに対 する適合性に及ぼすイオンプレーティングによる $\mathrm{Al}_{2} \mathrm{O}_{3}$ 被覆の効果を, $\mathrm{CF}$ にアルミウムを $1 \mu \mathrm{m}$ 被覆して作 った単繊維状 FRM の熱処理 $(18 \mathrm{ks})$ による強度劣化お よび黒鉛基板によるシミュレーション実験でのアルミニ ウムとのぬれ（接触角）と接着力により評価して, 次の 結果を得た。
（1）単繊維状 FRM は723 K になると強度劣化する。 強度劣化した FRM の引張強さは混合型ワイブル分布を とる。この低強度側の破断は反応に起因するもので，破 断強度はワイブル形状係数が約 2 と小さく，ばらつきが 大きい。

(2) $\mathrm{CF}$ 表面に被覆した $\mathrm{Al}_{2} \mathrm{O}_{3}$ は $\mathrm{CF}$ のアルミニウム との反応障壁とし有効で, $0.25 \mu \mathrm{m}$ の被覆で単瀻維状 FRM の反応による強度劣化開始温度を $723 \mathrm{~K}$ から 823 $\mathrm{K}$ 以上にまで向上させる。

(3) $\mathrm{Al}_{2} \mathrm{O}_{3}$ 被膜はアルミニウムとぬれや接着性が悪い が， $1.0 \mu \mathrm{m}$ のアルミニウムの被覆により FRM 強度を 劣化させないで改善できる。

(4) $\mathrm{Al}_{2} \mathrm{O}_{3}$ 被膜のアルミニウムとのぬれ性改善には $\mathrm{Ni}$ 被覆が，そして接着性改善には $\mathrm{Ni}$ と $\mathrm{Ti}$ 被覆がきわ めて有効であるが，しかし， $\mathrm{Al}$ との反応により生じる $\mathrm{Al}_{3} \mathrm{Ni}$ および $\mathrm{Al}_{3} \mathrm{Ti}$ は FRM 強度を劣化させる。

\section{参 考 文 献}

1) M. F. Amateau: J. Comp. Mater., 10 (1976), 279.

2) L. Aggour, E. Fitzer, M. Heym and E. Ignatowitz: Thin Solid Films, 40 (1977), 97.

3) A. G. Kulkarni, B. C. Pai and N. Balasubramanian: J. Mater. Sci.,14 (1979), 592.

4）小原嗣朗, 武藤範雄, 今西良文：日本金属学会誌, 43 (1979), 589.

5）小原嗣朗, 武藤範雄：同上, $44(1980), 271$.

6) M. Kh. Shorskorov, V. P. Alekhin, S. M. Savvateeva, V. B. Fedorov and T. A. Chernyshova: Thin Solid Films, 54 (1978), 279.

7) A. Miyase and K. Piekarski: J. Mater. Sci., 16 (1981), 251.

8) E. Fitzer and G. Jacobsen: Proc. of ICCM-IV, (1982), 1315.

9) A. Shindo and K. Honjo: Proc. Japan-U. S. CGMIII, (1986), 767.

10）浅沼 博, 大蔵明光 : 日本金属学会誌, 48 (1984), 1198.

11) T. Ohsaki, M. Yoshida, Y. Fukube and K. Nakamura: Thin Solid Films, 45 (1977), 563.

12) S. Kohara and N. Muto: Proc. of ICCM-V, (1984), 631.

13）たとえば，真壁 肇：ワイブル確率紙の使い方, 日本工業規格協会，（1966）, 57 .

14) G. Blankenburgs: J. Aust. Inst. Met., 14 (1969), 236.

15) A. Okura and K. Motoki: Comp. Sci. Tech., 24 (1985), 243.

16）北原 晃, 今川耕二, 長田純夫, 秋山茂, 上野 英俊：軽金属学会第59回秋期大会講演概要集, (1980), 97 .

17）森 信幸, 空野博明, 北原 晃, 大城桂作, 松田 公扶：日本金属学会誌，47(1983)，1132. 